\title{
The Impact of Organisational Culture on Employees' Productivity: A Comprehensive Systematic Review
}

\author{
Silas Mutie Nzuva* \\ CloudFuse Systems \\ Nairobi Kenya \\ Email: nzuvah@gmail.com \\ Purity Mwende Kimanzi \\ Mount Kenya University \\ Nairobi Kenya \\ Email: pmwende98@gmail.com
}

\begin{abstract}
Organisational culture greatly affects how an organisation operates and how the workforce interacts to carry out daily activities. Various scholars have linked strong organisational culture to high workforce productivity as a whole; the effect on specific constructs of productivity is yet to be outset. The main aim of this thesis was to analyse the link between organisational culture and employees productivity and outsets the specific effect of organisational culture on employees, motivation, commitment and leadership effectiveness, which are core components of workforce productivity. The research design took the form of a systematic review based on the structural-functionalist and ecological adaptation theories to ensure the validity and reliability of the findings. The research question was formulated using the PICOC Framework (Population, Intervention, Comparison, Outcome and Context). Specific keywords and phrases were used to search relevant articles in four research databases: ProQuest, EBSCO host, Emerald Insight, and Elsevier. 18 studies were sampled for the research. They were then summarised, synthesised, critiqued and compared to answer the research question. The findings from the study are herein presented.
\end{abstract}

Keywords: Organisational culture, employees' productivity, organisational performance, performance management, employees' motivation.

DOI: $10.7176 / \mathrm{EJBM} / 14-4-05$

Publication date: February $28^{\text {th }} 2022$

\section{Introduction}

The success of a firm is greatly dependent on the productivity of the employees as well as the underlying organisational culture. Organisational culture can be perceived as a set of values, beliefs, assumptions, and ways of interaction within an organisation, which emerges with time aid in the creation of a specific functional psychological and social environment that supports the firm's offerings. However, organisational management can shape the organisational culture as desired in an effort to bolster organisational performance. In line with this, Schein (2011) explains that the organisational culture that an organisation adopts bears the ability to negatively or positively shape the employees' behaviours and attitudes. This underpins the need for the organisation leadership to ensure that a culture that promotes interdepartmental collaboration and generation of synergy is adopted. Alvesson (2012) defines organisational culture as the beliefs, values, assumptions, and ways of life that results in a unique psychological and social environment that shapes how people interact and generally behave. As such, organisational culture is something that develops with time and is ultimately defined by the organisational philosophy, experiences, expectations, and values. Therefore, organisational culture affects individual member behaviours and depicted employees interactions, inner workings, and even self-image. Schein (2011) argues that productive organisational culture is characterised by shared written and unwritten rules, customs, beliefs, and attitudes that are considered valid and contribute to all organisational stakeholders' mutual benefit.

Afsar and Umrani (2019) explain that to ensure maximum productivity of the employees; an appropriate organisational culture has to be developed; a culture that promotes interdepartmental collaboration and the formation of functional teams to carry out specific tasks. Furthermore, the employees must also be motivated to effectively carry out their tasks. A study by Lăzăroiu (2015) linked high employee motivation with a positive attitude at the workplace. On the same note, a positive attitude combined with great motivation cultivates a positive psychological climate by the employees, which in turn results in a good organisational climate, one of the essential elements of the organisational culture. Over the decades, various scholars have studied the concept of organisational culture and how it influences organisational performance and employees productivity; the effect on specific indicators of employees productivity is yet to be fully explored. Workforce productivity is a function of the employees' commitment, motivation, and leadership effectiveness. It is no doubt that 
organisational culture significantly affects these productivity constructs, which in turn determines the overall organisation performance. Organisational leaders who do not understand the productivity of the employees' risk declined performance in the short term and compromise the implementation of functional strategies that are aimed at improving the profit margins in the long term (Ramdhani, Ramdhani \& Ainissyifa, 2017). Therefore, understanding the link between organisational culture and employees' productivity in terms of commitment, motivation, and leadership effectiveness is a subject that ought to be fully explored to understand how the culture can be leveraged to enhance organisational profitability.

Employees' productivity denotes the efficiency of an employee in carrying out a particular task. Lăzăroiu (2015) adds to this definition by explaining that employees' productivity is also assessed by the goods and services provided in unit time. Increased productivity implies that the number of goods and services provided per unit time have increased, compared to a previous point in time, without compromising quality. Among other things, Becker et al. (2018) explain that the productivity of the employees can be increased through investment in advanced technologies, which aid in increasing the rate of execution of specific tasks and improving the overall output. On the other hand, Hartnell et al. (2011) explain that labour is also a unit of prediction, and the increment of the employees bears a significant factor in enhancing the overall production of a firm; however, this increase the organisational costs and hence must be highly controlled. Furthermore, in the majority of the cases, the number of the employees is usually optimal, which implies that their increment would result in insignificant marginal output; this necessitates the need for empowering and promoting the productivity of the existing employees. Naranjo-Valencia, Jiménez-Jiménez, and Sanz-Valle (2011) posit that organisational culture encompasses four main elements: work processes, leadership style, organisational climate, and organisational values. Organisational values are intangible, but their impact is felt by all the organisational stakeholders. Zheng et al. (2011) explain that it is impossible for an organisation to establish a strong culture without establishing specific values that bind all organisational actions. It is through the organisational values that an individual can be held responsible and accountable for their actions.

A study by Zheng, Yang, and McLean (2011) show that a poor organisational culture, characterised by the lack of innovativeness, motivation, and commitment, is associated with vast negative implications, ranging from reduced employee morale to declined organisational performance. This is specifically true when considering the fact that organisational culture is used in experiencing the organisational vision, systems, norms, values, and beliefs; hence, a weak organisational culture jeopardises the ability of the leaders to institute functional rules and regulations to steer productivity. The study by Ostroff, Kinicki and Muhammad (2012) indicated that organisational culture determines how business decisions are made, in addition to business survival techniques. As such, new employees in an organisation are usually expected to assimilate organisational culture for them to be perceived fit for the position in question.

On a different point of view, whereas organisational culture is something that grows and strengthens with time, the lack of strong leadership skills can weaken and ultimately obliterate the established culture. Essentially, a strong organisational culture motivates the employees to execute their jobs diligently in support of the corporate goals. In his investigation of organisational culture, Schein (2011) asserts that the concept of organisational culture has grown over time, the latter being associated with things such as innovations, creativity, dynamism, and entre-premiership in the 21 st century.

\subsection{Research Question}

For organisational employees working in medium-size and large-size enterprises, how does a strong organisational culture compared to weak organisational culture affect workforce productivity

\subsection{Theoretical Framework}

\subsubsection{The Structural - Functionalist Theory}

This is one of the widely used theories on organisational culture. This theory is an improved version of the functionalist philosophy that was widely supported by Malinowski. In the structural-functionalist theory, an organisation is perceived to comprise people with goals, purpose, needs and who functionally interact with the internal and external environment to fulfil their needs and goals (Parsons, 2017). According to Parsons (2017), the organisational cultural system is usually in line with the prevailing social system, and the culture adopted by the organisation cannot be different from the immediate society. Furthermore, the scholars argue that the organisational culture is simply a higher orders value system, which is part of a more comprehensive and explicitly social system. From the structural-functionalist school of thought, it can be denoted that organisational culture is pervaded by ambient societal values, which then allow for the legitimation of the organisational activities and goals (Parsons, 2017). In the present case, organisational culture is believed to have a significant impact on the overall productivity of the employees. This relationship can be well investigated by drawing for the structural-functionalist paradigm, which perceives organisational culture as a high order sub value system that is derived from the values of an ideal society with the aim of supporting the goals, purpose, and needs of the 
organisations. Organisational goals include steps undertaken to minimise the time required to deliver orders to customers and how to minimise wastage of resources, while the purpose of the organisation is to establish a system that ensures that employees are working effectively. Additionally, organisational needs include growth and development, financial health, and a strong synergy between units.

1.1.1 The Ecological Adaptation Theory

This paradigm holds culture as a system of behavioural patterns that are socially transmitted and which aid the people in relating among themselves and also with their environment (Nahemow, Lawton and Center, 2016). With respect to organisational culture, this perspective holds that the latter is a sociocultural system that may take different forms but must adapt to the prevailing societal norms, environmental characteristics, and political factors. Furthermore, the researchers in support of this ideology argue that the processes and operations of an organisation are affected by the prevailing societal culture, which is another contingency factor. Nevertheless, organisational culture is not rigid but rather a social system that must be adjusted to match different contexts over time as it affects the overall outcomes of the various operations and processes (Nahemow et al., 2016). Therefore, different organisations may depict varying degrees of societal values. Therefore, just like the structural-functionalist perspective, the organisational culture can be perceived as a subsystem, which may be quite distinct from the surrounding societal values but change with time in order to accommodate any changes in the external and internal environment that affect how the organisation operates. This theory will be of optimal importance in identifying how the organisational culture has shifted over time, based on the prevailing context.

\section{Methods}

\subsection{Research Design}

In this study, the researcher adopted a systematic review approach. Booth, Sutton, and Papaioannou (2016) define a systematic review as a research design in which the researcher collects, summarises and synthesises empirical evidence from numerous studies to sufficiently answer the set research question. Systematic reviews focus on identifying, evaluating, and summarising the findings concerning organisational issues, thus, allowing decision-makers to access evidence-based information. On the same note, Booth et al. (2016) note that a researcher must identify and pride a complete and exhaustive summary of the available knowledge with respect to the outlined research question. Therefore, inclusion and exclusion criteria for the studies must be defined; the inclusion criteria denote the characteristics of the studies to be included, while the exclusion critical defines the characteristics of the studies to be excluded. It is of optimal importance for the researcher to formulate a research question that lies within the scope of the available evidence.

\subsection{Inclusion Criteria}

Since the study was primarily secondary as it relied on other studies for the data, it was cortical to ensure that the sources used in the study met the quality threshold. For a study to be sampled for the peer review, it must have been published between 2009 and 2019 to offer the latest trends in research; the researchers must have used either qualitative or quantitative research design; the research must have entailed empirical collection and analysis of data, the researchers must have investigated the effect of organisational culture on employee's productivity or the measured employees' motivation as a function of organisational culture; the outcomes of the included studies must have been employee productivity, the studies must be relevant to medium and large-sized organisations.

With respect to exclusion criteria, studies that are older than 10 years, as well as those that used secondary data collection, were excluded. Furthermore, studies that included corporate culture effect on the personal lives of the employees were excluded.

\subsection{Search Strategy, Keywords, and Results}

The researcher performed a keyword search on four main databases; ProQuest, EBSCO host, Emerald Insight, and Elsevier. In order, filters were applied. This entailed limiting the publication dates to 2016 to date, including the only peer-reviewed studies and filtering articles only written in English and finally. The following keyword and keyword combinations were used in each of the four databases:

Organisational culture; employees' performance; workforce performance; employee productivity; employees' motivation; organisational climate; organisational performance; corporate culture; corporate values; employees compartment; employed dedication; employees' attitude; leadership effectiveness 


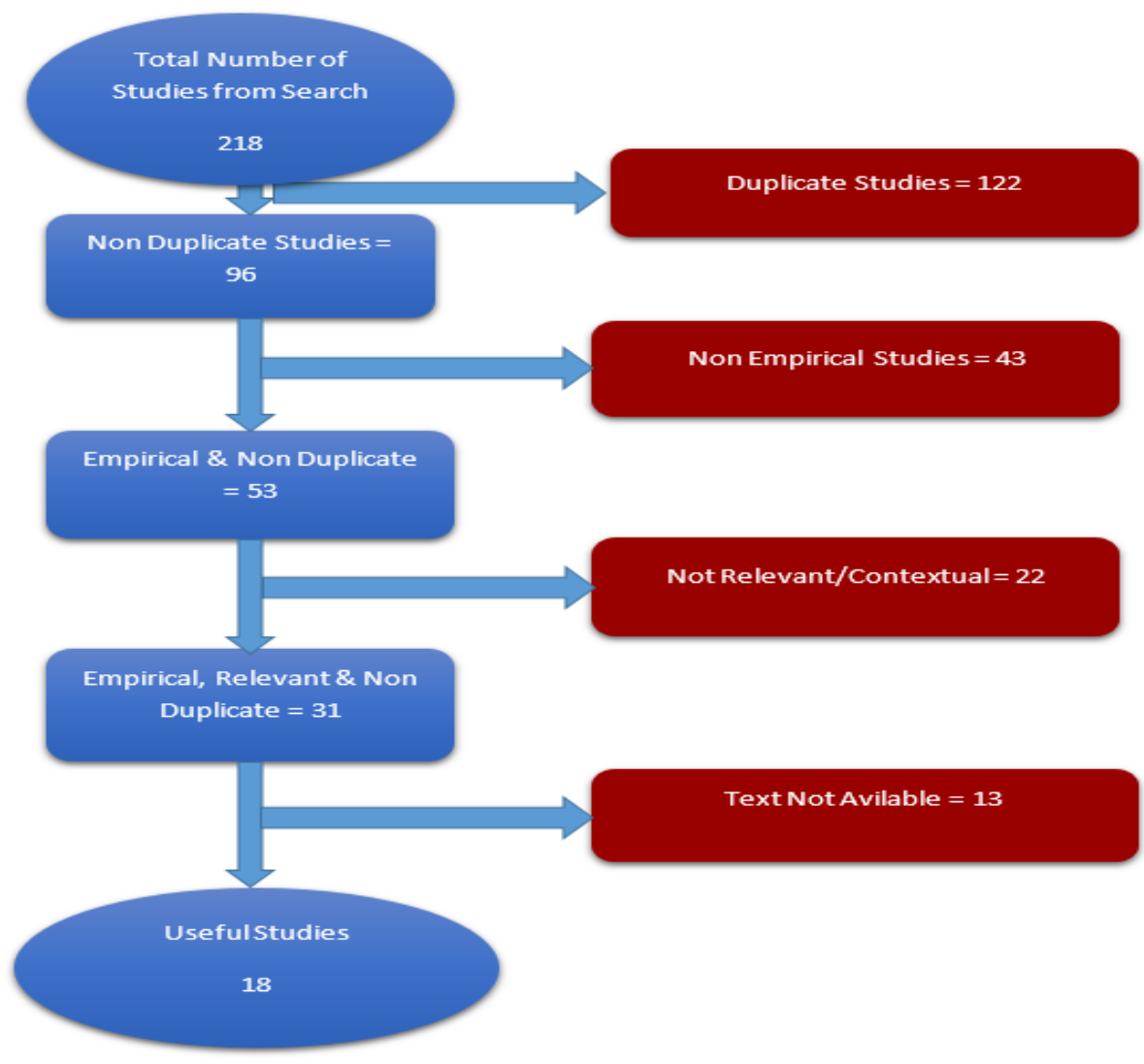

Figure 1: Diagrammatic representation of the inclusion and exclusion process

\section{Results}

\subsection{Research Design}

This study involves a review of 18 scholarly journals that focused on the implications of organisational culture on employee performance. Some of the studies that utilised survey method include Pawirosumarto, Setyadi and Khumaedi (2017); Karneli et al. (2015); Sivakami and Samitha (2018); Williams and Glisson (2013); Meng and Berger (2019); Lee, Shiue and Chen (2016); and Isa, Ugheoke and Noor (2016). Salehipour and Ahmand (2018) and Sahat et al. (2018) used a quantitative approach to gather data, while Ibrahim (2017) utilised a classical assumption test to undertake a linearity test and to determine the link between variables. Braithwaite et al. (2017) carried out a systematic review, as well as a meta-analysis using the literature search of various academic databases, such as CINAHL, Ovid MEDLINE, EMBASE, PsycINFO, and Web of Science. Taylor et al. (2018) also utilised a systematic review and randomised controlled trials to demonstrate how organisational culture can influence productivity within the healthcare settings.

\begin{tabular}{|c|c|c|c|c|c|}
\hline Author \&Year & Sector/Population & $\begin{array}{l}\text { Design }{ }^{+} \\
\text {Sample Size }\end{array}$ & Main Findings & Limitations & Conclusion \\
\hline $\begin{array}{lll}\text { Taylor } & \text { et al. } \\
(2018) & & \end{array}$ & $\begin{array}{l}\text { Employees at their } \\
\text { workplace. }\end{array}$ & $\begin{array}{l}\text { Randomised } \\
\text { control trials } \\
(\mathrm{RCTs}) \text { and } \\
\text { systematic } \\
\text { review } \\
\text { procedure, } \mathrm{N}= \\
77 \text { relevant } \\
\text { articles, and } 8 \\
\text { publications }\end{array}$ & $\begin{array}{l}\text { Minimising sedentary behaviour within the } \\
\text { workplace is critical for the success of the } \\
\text { organisation's operations. The results from the } \\
\text { study indicate that more workplace } \\
\text { interventions were required to minimise sitting } \\
\text { time at work through organisational culture. } \\
\text { The workplace interventions helped in } \\
\text { decreasing sitting time by about } 80 \mathrm{~min} / 8 \text { hours } \\
\text { workday, as well as increasing the standing } \\
\text { time by about } 72 \mathrm{~min} / 8 \text { hours workday. } \\
\text { Organisational culture has an effect on } \\
\text { workplace behaviours; thus, influencing } \\
\text { performance and productivity. Thus, the } \\
\text { researchers were able to offer more knowledge } \\
\text { on what organisations can do to enhance } \\
\text { employee productivity. }\end{array}$ & $\begin{array}{l}\text { The study included } \\
\text { only articles published } \\
\text { in English. Majority of } \\
\text { the articles utilised } \\
\text { focus groups, where } \\
\text { members are not likely } \\
\text { to express their } \\
\text { personal opinions to } \\
\text { avoid conflict with } \\
\text { their colleagues. The } \\
\text { study also excluded } \\
\text { unpublished theses and } \\
\text { dissertations. The } \\
\text { study recommends } \\
\text { more interventions to } \\
\text { minimise the } \\
\text { possibility of biases. }\end{array}$ & $\begin{array}{l}\text { This study warned } \\
\text { employees on } \\
\text { prolonged sitting, } \\
\text { which increases the } \\
\text { risk of } \\
\text { cardiometabolic } \\
\text { diseases, as well as } \\
\text { premature mortality. } \\
\text { Accordingly, } \\
\text { organisational } \\
\text { culture contributes to } \\
\text { transforming } \\
\text { workplace } \\
\text { behaviours, in } \\
\text { addition to the } \\
\text { implementation of } \\
\text { health promotion } \\
\text { initiatives. }\end{array}$ \\
\hline
\end{tabular}




\begin{tabular}{|c|c|c|c|c|c|}
\hline Author \&Year & Sector/Population & $\begin{array}{l}\text { Design } \\
\text { Sample Size }\end{array}$ & Main Findings & Limitations & Conclusion \\
\hline $\begin{array}{l}\text { Naranjo- } \\
\text { Valencia, } \\
\text { Jimenez- } \\
\text { Jimenez\& } \\
\text { Sanz-Valle } \\
(2016)\end{array}$ & $\begin{array}{lr}\text { Spanish } & \\
\text { organisations } & \text { with } \\
\text { at least } & 15 \\
\text { employees. } & \end{array}$ & $\begin{array}{l}\text { Descriptive } \\
\text { research, N= } \\
446 \\
\text { respondents }\end{array}$ & $\begin{array}{l}\text { The study depicts a positive connection } \\
\text { between innovation and performance. The } \\
\text { results show that organisational culture } \\
\text { determines firm innovation, where it can foster } \\
\text { or limit innovation. Out of the four types of } \\
\text { cultures indicated in the study, the adhocracy } \\
\text { culture had the highest positive impact on } \\
\text { performance. Clan and market cultures did not } \\
\text { show any effect on innovation that could create } \\
\text { an impact on performance. The negative } \\
\text { influence of hierarchy culture only implies that } \\
\text { the aspect of innovation has been strengthened } \\
\text { to enhance performance. The results ensure that } \\
\text { innovation becomes the mediator of the } \\
\text { positive effects of adhocracy on employee } \\
\text { productivity. }\end{array}$ & $\begin{array}{l}\text { The study does not } \\
\text { exhibit limitations, as } \\
\text { the two categories of } \\
\text { studies did not show } \\
\text { significant differences. } \\
\text { However, the main } \\
\text { problem was } \\
\text { identifying a suitable } \\
\text { measure for the firm's } \\
\text { performance since it is } \\
\text { relatively hard to } \\
\text { obtain financial } \\
\text { measures in a given } \\
\text { performance. }\end{array}$ & $\begin{array}{l}\text { The findings in this } \\
\text { study can assist } \\
\text { managers in } \\
\text { developing an } \\
\text { organisational } \\
\text { culture that enhances } \\
\text { both innovation and } \\
\text { performance. In this } \\
\text { case, the adhocracy } \\
\text { culture has a positive } \\
\text { influence } \\
\text { employee on } \\
\text { productivity. }\end{array}$ \\
\hline $\begin{array}{l}\text { Braithwaite et } \\
\text { al. (2017) }\end{array}$ & $\begin{array}{l}\text { A variety of } \\
\text { healthcare } \\
\text { organisations }\end{array}$ & $\begin{array}{l}\text { A systematic } \\
\text { review, N= } \\
204 \text { articles, } \\
\text { which were } \\
\text { eligible for } \\
\text { review. }\end{array}$ & $\begin{array}{l}\text { Based on the findings, organisational and } \\
\text { workplace cultures were positively related to } \\
\text { patient outcomes in terms of reduced falls, } \\
\text { mortality rates, as well as hospital-acquired } \\
\text { infections. Over } 90 \% \text { of studies indicated that } \\
\text { organisational culture is linked to patient } \\
\text { outcomes. Only a few articles }(8.1 \%) \text { showed } \\
\text { no significant relationship between culture and } \\
\text { employee outcomes. Some aspects of } \\
\text { organisational culture that influence } \\
\text { performance include goals, attitudes, } \\
\text { behaviours, and beliefs. Four controlled } \\
\text { variables that determined the level of } \\
\text { innovation and performance and which were } \\
\text { incorporated in the analyses were industry, age, } \\
\text { strategy, and size. }\end{array}$ & $\begin{array}{l}\text { Definitions, as well as } \\
\text { measurements of } \\
\text { culture and patient } \\
\text { outcomes, seemed to } \\
\text { be highly variable, } \\
\text { leading to limits on } \\
\text { comparisons. } \\
\text { Additionally, } \\
\text { developing systematic } \\
\text { reviews take a long } \\
\text { time (18-24 months) to } \\
\text { become a publication. }\end{array}$ & $\begin{array}{l}\text { The review indicated } \\
\text { that there was a } \\
\text { positive association } \\
\text { between } \\
\text { organisational } \\
\text { culture and the } \\
\text { outcomes in various } \\
\text { healthcare } \\
\text { organisations across } \\
\text { different settings and } \\
\text { countries. }\end{array}$ \\
\hline $\begin{array}{l}\text { Shah \& Parmar } \\
(2016)\end{array}$ & $\begin{array}{l}\text { The study covers } \\
\text { employees at } \\
\text { Adani Enterprises } \\
\text { Ltd, in ABEX } \\
\text { Department }\end{array}$ & $\begin{array}{l}\text { A survey was } \\
\text { carried out } \\
\text { through } \\
\text { random } \\
\text { sampling, } \mathrm{N}= \\
40 \text { employees }\end{array}$ & $\begin{array}{l}\text { The study indicates that the numerous } \\
\text { parameters of organisational culture seemed to } \\
\text { have an impact on employee productivity. A } \\
\text { strong organisational culture is essential for } \\
\text { retaining employees, strengthening the } \\
\text { company's brand, as well as increasing } \\
\text { productivity and efficiency. The organisational } \\
\text { culture encourages employees to share ideas, } \\
\text { knowledge, as well as skills as they collaborate } \\
\text { to attain organisational goals. From the } \\
\text { analysis, the significant value of } 0.000 \text {, which } \\
\text { is below the set significant value of } 0.005 \text {, } \\
\text { leads to the rejection of the null hypothesis and } \\
\text { agree on an alternative hypothesis indicating } \\
\text { that the employees are flexible as well as } \\
\text { adaptable to change. }\end{array}$ & $\begin{array}{l}\text { It is difficult to } \\
\text { generalise a study from } \\
\text { a single department. } \\
\text { The study does not } \\
\text { explain how the } \\
\text { number of respondents } \\
\text { in the sample was } \\
\text { decided. Random } \\
\text { sampling usually limits } \\
\text { an addition of } \\
\text { knowledge concerning } \\
\text { the participants while it } \\
\text { fails to get rid of } \\
\text { internal bias during the } \\
\text { process. }\end{array}$ & $\begin{array}{l}\text { Generally, the study } \\
\text { revealed that positive } \\
\text { organisational and } \\
\text { workplace cultures } \\
\text { tend to be closely } \\
\text { linked to employee } \\
\text { productivity. The } \\
\text { study concluded that } \\
\text { a strong } \\
\text { organisational } \\
\text { culture is vital for } \\
\text { employee retention, } \\
\text { in addition to } \\
\text { strengthening the } \\
\text { company's brand. }\end{array}$ \\
\hline $\begin{array}{l}\text { Paschal \& } \\
\text { Nizam (2016) }\end{array}$ & $\begin{array}{lr}\text { This study } & \text { was } \\
\text { undertaken in } & \text { in } \\
\text { SingTel mobile } \\
\text { telecommunication } \\
\text { company in } \\
\text { Malaysia. }\end{array}$ & $\begin{array}{l}\text { The study is a } \\
\text { literature } \\
\text { review with a } \\
\text { descriptive } \\
\text { research } \\
\text { design, } \mathrm{N}= \\
150 \\
\text { employees. }\end{array}$ & $\begin{array}{l}\text { The study revealed that organisational culture, } \\
\text { which incorporates rituals, values, as well as } \\
\text { heroes, tends to have a significant impact on } \\
\text { employee's performance. After performing } \\
\text { regression analysis, R squared was adjusted to } \\
0.919 \text {, based on the predictions, which implied } \\
\text { that } 91.9 \% \text { of the employee productivity was } \\
\text { predictable through the independent variables. } \\
91.9 \% \text { of the variance is acceptable as it is } \\
\text { above the minimum requirement for fitting the } \\
\text { model. Frequent ritual activities within } \\
\text { organisations make employees feel motivated } \\
\text { to succeed in their duties, thus, improving their } \\
\text { performance. Without rituals, it might be } \\
\text { difficult for managers to control their } \\
\text { employees within the workplace. }\end{array}$ & $\begin{array}{l}\text { In descriptive statistics, } \\
\text { no variables are } \\
\text { manipulated, which } \\
\text { implies that statistical } \\
\text { analysis is impossible. } \\
\text { The results of this } \\
\text { study cannot be } \\
\text { replicated; hence, they } \\
\text { are unreliable. The } \\
\text { study also covers a } \\
\text { single sector, which } \\
\text { makes it hard to } \\
\text { replicate the study } \\
\text { results to other sectors. }\end{array}$ & $\begin{array}{l}\text { The } \\
\text { emphasised thaty } \\
\text { organisational } \\
\text { culture has a strong } \\
\text { influence } \\
\text { employee } \\
\text { productivity. } \\
\text { Employees are likely } \\
\text { to replicate positive } \\
\text { behaviours from } \\
\text { their colleagues who } \\
\text { behave appropriately } \\
\text { within the } \\
\text { organisation. }\end{array}$ \\
\hline
\end{tabular}




\begin{tabular}{|c|c|c|c|c|c|}
\hline Author \&Year & Sector/Population & $\begin{array}{l}\text { Design } \\
\text { Sample Size }\end{array}$ & Main Findings & Limitations & Conclusion \\
\hline $\begin{array}{l}\text { Muliaty, Basri } \\
\& \text { Jasruddin } \\
(2017)\end{array}$ & $\begin{array}{lr}\text { One-Stop } \\
\text { Licensing } & \text { Service } \\
\text { and Investment } \\
\text { Agency } \\
\text { Makassar, } \\
\text { Indonesia. }\end{array}$ & $\begin{array}{l}\text { Explanatory } \\
\text { research, } \mathrm{N}= \\
86 \text { employees. }\end{array}$ & $\begin{array}{l}\text { Both organisational transformation and } \\
\text { organisational culture affect employee } \\
\text { productivity through job satisfaction. Cultural } \\
\text { transformation, which is part of organisational } \\
\text { change, has a direct effect on employee } \\
\text { productivity, as well as job satisfaction. } \\
\text { Organisational transformation facilitates the } \\
\text { changing of roles, which in turn make the } \\
\text { organisation become more responsive to } \\
\text { changes. The two significant paths in the path } \\
\text { analysis, which include job satisfaction to } \\
\text { employee productivity and organisational } \\
\text { transformation to job satisfaction, demonstrate } \\
\text { standardised coefficients of } 0,690 \text { and } 0,700 \text {, } \\
\text { respectively. Organisational culture tends to } \\
\text { differ based on the organisation's operations, } \\
\text { but it can be adjusted to correspond with the } \\
\text { organisational goals; hence, a change in } \\
\text { behaviours can help in enhancing employee } \\
\text { productivity to meet organisational goals. }\end{array}$ & $\begin{array}{l}\text { No limitation, as the } \\
\text { study covered all } \\
\text { employees in the } \\
\text { company. The study } \\
\text { does not offer any } \\
\text { serious limitation in } \\
\text { enhancing employee } \\
\text { productivity through } \\
\text { organisational culture. } \\
\text { However, the } \\
\text { exploratory method, } \\
\text { which offers } \\
\text { qualitative information, } \\
\text { is known to offer } \\
\text { interpretations that are } \\
\text { judgmental and } \\
\text { subjective. Findings } \\
\text { that are determined } \\
\text { through qualitative } \\
\text { research are likely to } \\
\text { experience interpreter } \\
\text { bias. }\end{array}$ & $\begin{array}{l}\text { Changes in the } \\
\text { organisational } \\
\text { culture will help in } \\
\text { boosting employee } \\
\text { productivity, as long } \\
\text { as the new } \\
\text { organisational } \\
\text { culture is favourable. } \\
\text { Employees are likely } \\
\text { to experience job } \\
\text { satisfaction when } \\
\text { organisational } \\
\text { culture } \\
\text { accommodates their } \\
\text { needs. }\end{array}$ \\
\hline $\begin{array}{l}\text { Salehipour \& } \\
\text { Ah mand } \\
(2018)\end{array}$ & $\begin{array}{l}\text { Iran Ministry of } \\
\text { Education. }\end{array}$ & $\begin{array}{l}\text { Quantitative } \\
\text { approach, } \\
\text { with a high- } \\
\text { performance } \\
\text { work system } \\
\text { (HPWS), } \\
\mathrm{N}=200 \\
\text { employees }\end{array}$ & $\begin{array}{l}\text { The study indicated that a strong organisational } \\
\text { culture is helpful in enhancing the performance } \\
\text { of employees. The study emphasised that } \\
\text { certain high-performance work system (HPWS) } \\
\text { dimensions influence employee's performance. } \\
\text { The organisational culture has a strong impact } \\
\text { on the country's ministry of education } \\
\text { members, as well as employee productivity. } \\
\text { The findings indicated that it was necessary to } \\
\text { carry out proper training for employees to } \\
\text { create a win-win situation where both } \\
\text { employees and the organisation would be } \\
\text { beneficiaries. Apart from training, the } \\
\text { researcher revealed that } 83.3 \% \text { of the } \\
\text { respondents had eleven years of experience, } \\
\text { which implied that being in an organisation for } \\
\text { a prolonged time can help in mastering the } \\
\text { organisational culture; hence, improving } \\
\text { performance. }\end{array}$ & $\begin{array}{l}\text { The study covered only } \\
\text { a single ministry in the } \\
\text { public sector; thus, it } \\
\text { cannot be replicated in } \\
\text { the private sector. One } \\
\text { of the limitations of the } \\
\text { HPWS approach is that } \\
\text { it treats employees as } \\
\text { abstracts instead of } \\
\text { active agents and } \\
\text { subjects. The study } \\
\text { also utilised a simple } \\
\text { random sampling } \\
\text { method, which is } \\
\text { costly and sluggish } \\
\text { when applied to a large } \\
\text { population. }\end{array}$ & $\begin{array}{l}\text { The study helps in } \\
\text { understanding the } \\
\text { relationship that } \\
\text { exists between } \\
\text { organisational } \\
\text { culture, HPWS, and } \\
\text { employee's } \\
\text { performance. The } \\
\text { study suggests that } \\
\text { the current } \\
\text { organisations must } \\
\text { work hard to meet } \\
\text { stakeholders' } \\
\text { expectations. }\end{array}$ \\
\hline $\begin{array}{l}\text { Isa, Ugheoke \& } \\
\text { Noor (2016) }\end{array}$ & $\begin{array}{l}6 \text { departments } \\
\text { within the } \\
\text { Ministry of } \\
\text { Education, Oman. }\end{array}$ & $\begin{array}{l}\text { A survey } \\
\text { study, } \mathrm{N}=250 \\
\text { employees }\end{array}$ & $\begin{array}{l}\text { Two out of three types of cultural dimensions } \\
\text { indicted in this study revealed that culture has a } \\
\text { positive influence on the employee's } \\
\text { performance. In particular, the bureaucratic } \\
\text { culture tends to have a positive impact on } \\
\text { employees' performance. The cultures of public } \\
\text { organisations in Oman tend to be skewed } \\
\text { towards bureaucracy, which interferes with a } \\
\text { smooth flow of information. The study does } \\
\text { not support an innovative culture, as it does not } \\
\text { have a significant effect on employee } \\
\text { productivity in the public sector. }\end{array}$ & $\begin{array}{l}\text { Individual } \\
\text { confidentiality was } \\
\text { limited by hiding the } \\
\text { names of the } \\
\text { respondent. Survey } \\
\text { research does not } \\
\text { encourage respondents } \\
\text { to offer accurate } \\
\text { answers, which could } \\
\text { lead to bias. The study } \\
\text { also targeted the } \\
\text { private sector; hence, it } \\
\text { cannot be replicated in } \\
\text { the public sector. }\end{array}$ & 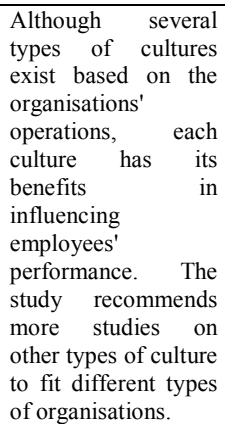 \\
\hline $\begin{array}{l}\text { Lee, Shiue \& } \\
\text { Chen, (2016) }\end{array}$ & $\begin{array}{l}\text { This study was } \\
\text { carried out in SPI- } \\
\text { certified } \\
\text { Taiwanese } \\
\text { organisations }\end{array}$ & $\begin{array}{lr}\text { The r } & \text { survey, } \\
\mathrm{N}= & 118 \\
\text { employees }\end{array}$ & $\begin{array}{l}\text { The clan-type organisational culture is closely } \\
\text { linked to knowledge sharing, which, in turn, } \\
\text { contributes to SPI success. The results } \\
\text { demonstrated that SPI-knowledge sharing } \\
\text { influences SPI success, as revealed by the } \\
\text { hypotheses. The findings reveal that software } \\
\text { process knowledge should be shared in order to } \\
\text { enhance the effectiveness of software } \\
\text { processes. Combining the aspects of knowledge } \\
\text { management, as well as software process } \\
\text { management, helps in utilising digital tools to } \\
\text { foster collaboration, in addition to sharing } \\
\text { knowledge within the organisation, with } \\
\text { respect to SPI. Organisational culture is utilised } \\
\text { to explain how SPI can be implemented } \\
\text { successfully. }\end{array}$ & $\begin{array}{l}\text { The findings cannot be } \\
\text { generalised because } \\
\text { they focused on the } \\
\text { Capability Maturity } \\
\text { Model Integration } \\
\text { (CMMI) approach } \\
\text { only. The probability } \\
\text { of having a common } \\
\text { method bias problem is } \\
\text { high when the survey } \\
\text { data are collected } \\
\text { through self-report. }\end{array}$ & $\begin{array}{l}\text { The findings } \\
\text { highlight how clan } \\
\text { culture helps in } \\
\text { knowledge sharing } \\
\text { and SPI success. The } \\
\text { findings also } \\
\text { incorporate the need } \\
\text { to enhance } \\
\text { knowledge on how } \\
\text { organisational } \\
\text { culture, as well as } \\
\text { good leadership, } \\
\text { contribute towards } \\
\text { SPI success. }\end{array}$ \\
\hline
\end{tabular}




\begin{tabular}{|c|c|c|c|c|c|}
\hline Author \&Year & Sector/Population & $\begin{array}{l}\text { Design }+ \\
\text { Sample Size }\end{array}$ & Main Findings & Limitations & Conclusion \\
\hline $\begin{array}{l}\text { Meng \& } \\
\text { Berger (2019) }\end{array}$ & $\begin{array}{lr}\text { A national study } \\
\text { on } & \text { PR } \\
\text { professionals } & \end{array}$ & $\begin{array}{l}\text { A cross- } \\
\text { sectional, } \\
\text { online survey, } \\
\mathrm{N}=838 \quad \mathrm{PR} \\
\text { professionals }\end{array}$ & $\begin{array}{l}\text { The findings indicate that organisational } \\
\text { culture, with the help of leader performance, } \\
\text { plays a crucial role in boosting job satisfaction } \\
\text { and work engagement among public relations } \\
\text { professionals. Work engagement was measured } \\
\text { by utilising the } 12 \text { items found in the employee } \\
\text { engagement survey. All measures incorporated } \\
\text { in this study were taken from previous research } \\
\text { but tailored for PR professionals to represent } \\
\text { their perceptions of organisational culture. The } \\
\text { findings imply that organisation leaders should } \\
\text { strive to utilise approaches that would assist in } \\
\text { enhancing trust between them and employees } \\
\text { in order to enhance performance. }\end{array}$ & $\begin{array}{l}\text { Cross-sectional design } \\
\text { studies are vulnerable } \\
\text { to biases due to their } \\
\text { incapacity to analyse } \\
\text { behaviours for a } \\
\text { prolonged period. } \\
\text { Work engagement may } \\
\text { vary due to age, } \\
\text { gender, and other } \\
\text { factors. A longitudinal } \\
\text { or a mixed design } \\
\text { could serve the } \\
\text { purpose in the future to } \\
\text { minimise bias. }\end{array}$ & $\begin{array}{l}\text { The effects of } \\
\text { organisational } \\
\text { culture on the PR } \\
\text { professionals' work } \\
\text { engagement are both } \\
\text { direct and indirect. } \\
\text { Enhancing trust } \\
\text { among employees } \\
\text { will help in } \\
\text { improving their } \\
\text { performance. } \\
\text { Employee } \\
\text { behaviours are tied } \\
\text { to organisational } \\
\text { culture; thus, their } \\
\text { performance is likely } \\
\text { to improve if their } \\
\text { organisations have a } \\
\text { strong organisational } \\
\text { culture. }\end{array}$ \\
\hline $\begin{array}{l}\text { Williams \& } \\
\text { Glisson (2013) }\end{array}$ & $\begin{array}{l}\text { National Survey of } \\
\text { Child and } \\
\text { Adolescent } \\
\text { Wellbeing } \\
\text { (NSCAW II) }\end{array}$ & $\begin{array}{l}\text { A national- } \\
\text { wide } \\
\text { probability } \\
\text { survey and 2- } \\
\text { stage stratified } \\
\text { sampling } \\
\text { design, } \mathrm{N}= \\
2,346 \text { young } \\
\text { people }(1.5-18 \\
\text { years }) \text { and } \\
1,544 \text { } \\
\text { caseworkers } \\
\text { in } 73 \text { child } \\
\text { welfare } \\
\text { agencies }\end{array}$ & $\begin{array}{l}\text { The results indicate that decreased caseworker } \\
\text { turnover is linked to improved outcomes for the } \\
\text { youth, but only when the caseworkers expect } \\
\text { the organisational culture to be above the } \\
\text { national average and commit to improving the } \\
\text { youth as its top priority. The study revealed } \\
\text { that proficient organisational culture responds } \\
\text { positively to caseworkers situations by } \\
\text { assessing their work environment and assisting } \\
\text { in meeting their expectations. Following the } \\
\text { tests of the hypotheses, the study indicated that } \\
\text { the interactions between turnover and } \\
\text { proficiency occurred after assessing the } \\
\text { relationship between employee turnover and } \\
\text { youth outcomes. A decline in caseworker } \\
\text { turnover implied improved youth outcomes } \\
\text { within the child welfare systems due to } \\
\text { proficient organisational culture. }\end{array}$ & $\begin{array}{l}\text { The study did not } \\
\text { include a random } \\
\text { assignment of the } \\
\text { youth to conditions } \\
\text { while the independent } \\
\text { variables were not } \\
\text { exposed to } \\
\text { manipulations. } \\
\text { Additionally, stratified } \\
\text { sampling can be } \\
\text { unreliable when the } \\
\text { researcher is not } \\
\text { capable of classifying } \\
\text { members of the } \\
\text { population into } \\
\text { different subgroups. }\end{array}$ & $\begin{array}{l}\text { Efforts should be } \\
\text { made to enhance } \\
\text { child } \\
\text { services welfare } \\
\text { minimising r staff } \\
\text { turnover r and } \\
\text { establishing cultures } \\
\text { that } r \text { make } \\
\text { caseworkers be } \\
\text { responsive to the } \\
\text { requirements of the } \\
\text { youth. }\end{array}$ \\
\hline $\begin{array}{l}\begin{array}{l}\text { Sahat } \\
(2018)\end{array} \\
\text { et al. }\end{array}$ & $\begin{array}{l}\text { The study covered } \\
\text { employees of } \\
\text { Bank Tabungan } \\
\text { Negara (BTN) in } \\
\text { five regions across } \\
\text { Indonesia. }\end{array}$ & $\begin{array}{l}\text { A quantitative } \\
\text { research } \\
\text { approach with } \\
\text { generalised } \\
\text { structured } \\
\text { component } \\
\text { analysis } \\
\text { (GSCA). The } \\
\text { study utilises } \\
\text { a } \\
\text { representative } \\
\text { sample, N= } \\
166 \text { respondents. }\end{array}$ & $\begin{array}{l}\text { The findings indicated that servant leadership } \\
\text { attracted rewards, as well as increased job } \\
\text { satisfaction. Performance is likely to improve } \\
\text { through servant leadership, while } \\
\text { organisational culture influences employee } \\
\text { productivity. The study also revealed that } \\
\text { servant leadership affects organisational } \\
\text { culture. However, different results indicated } \\
\text { that servant leadership does not influence } \\
\text { employee productivity. }\end{array}$ & $\begin{array}{l}\text { Although GSCA is } \\
\text { essential for structural } \\
\text { equation modelling, } \\
\text { the chances of offering } \\
\text { inconsistent estimates } \\
\text { are quite high. The } \\
\text { study seems to favour } \\
\text { servant leadership, } \\
\text { which can be costly to } \\
\text { establish, as it takes } \\
\text { time before it } \\
\text { manifests itself in } \\
\text { leaders. }\end{array}$ & $\begin{array}{l}\text { The study supports } \\
\text { servant leadership } \\
\text { for offering rewards, } \\
\text { thus, shaping } \\
\text { organisational } \\
\text { culture. However, } \\
\text { servant leadership is } \\
\text { unlikely to influence } \\
\text { employee } \\
\text { productivity. }\end{array}$ \\
\hline $\begin{array}{l}\text { Sivakami \& } \\
\text { Samitha (2018) }\end{array}$ & $\begin{array}{lr}\begin{array}{l}\text { Software } \\
\text { employees }\end{array} \\
\text { Source } & \text { of } \\
\text { Software } & \\
\text { Technologies } & \text { Pvt } \\
\text { Ltd } & \end{array}$ & $\begin{array}{l}\text { Non- } \\
\text { probability } \\
\text { sampling, N= } \\
50 \text { employees. } \\
\text { The study } \\
\text { utilised } \\
\text { questionnaires } \\
\text { with } 12 \\
\text { questions, } \\
\text { which were } \\
\text { filled by the } \\
\text { employees. }\end{array}$ & $\begin{array}{l}\text { The findings illustrate a strong connection } \\
\text { between employee productivity and } \\
\text { organisational culture. } 16 \% \text { of employees } \\
\text { believe that their organisation has established } \\
\text { achievable goals, while } 48 \% \text { of employees are } \\
\text { convinced that the organisation has employees } \\
\text { with the necessary skills to attain the goals. The } \\
\text { survey data include information on competitive } \\
\text { culture, individual employee productivity, and } \\
\text { organisational performance. The findings also } \\
\text { indicated that organisational culture helped in } \\
\text { creating stability in the workplace since } \\
\text { employees are convinced that the organisation } \\
\text { respects them by involving them in decision } \\
\text { making. }\end{array}$ & $\begin{array}{l}\text { The results cannot be } \\
\text { generalised because } \\
\text { there were no equal } \\
\text { chances rof } \\
\text { representation. Data } \\
\text { from self-administered } \\
\text { questionnaires may not } \\
\text { be reliable, as the } \\
\text { targeted respondents } \\
\text { may not understand } \\
\text { some questions or may } \\
\text { allow other people to } \\
\text { fill the questionnaire } \\
\text { on their behalf. }\end{array}$ & $\begin{array}{l}\text { The organisation has } \\
\text { the capacity of } \\
\text { enhancing employee } \\
\text { job performance by } \\
\text { improving } \\
\text { communication and } \\
\text { encouraging healthy } \\
\text { competition among } \\
\text { teams. }\end{array}$ \\
\hline $\begin{array}{l}\text { Hendrik, } \\
\text { Moch, } \\
\text { Madhakomala } \\
\text { \& Suratman } \\
(2018)\end{array}$ & $\begin{array}{l}\text { A study on } \\
\text { employees of } \mathrm{PT} \text {. } \\
\text { ATB }\end{array}$ & $\begin{array}{l}\text { The study is a } \\
\text { quantitative } \\
\text { research } \\
\text { design, with } \\
\text { PT ATB form } \\
\text { of unit } \\
\text { analysis, N= } \\
\begin{array}{l}233 \\
\text { employees. }\end{array}\end{array}$ & $\begin{array}{l}\text { Transformational leadership has an impact on } \\
\text { organisational change, which, in turn, } \\
\text { influences employee productivity. The findings } \\
\text { corresponded with the empirical results, which } \\
\text { indicated that organisational culture influences } \\
\text { employee productivity, thus, enabling them to } \\
\text { grow and develop. The direct effect of } \\
\text { organisational culture on employee } \\
\text { productivity is } 17.8 \% \text { due to transformational } \\
\text { leadership, and the indirect effect stands at } \\
5.1 \% \text {. }\end{array}$ & $\begin{array}{l}\text { The study does not } \\
\text { have limitations, as the } \\
\text { level of influence is } \\
\text { positive. }\end{array}$ & $\begin{array}{l}\text { The effect of } \\
\text { organisational } \\
\text { culture on employee } \\
\text { productivity is } \\
\text { positive but indirect. } \\
\text { Hence, the } \\
\text { organisation requires } \\
\text { an organisational } \\
\text { culture that has a } \\
\text { foundation for } \\
\text { transformational } \\
\text { leadership. }\end{array}$ \\
\hline
\end{tabular}




\begin{tabular}{|c|c|c|c|c|c|}
\hline Author \&Year & Sector/Population & $\begin{array}{l}\text { Design }+ \\
\text { Sample Size }\end{array}$ & Main Findings & Limitations & Conclusion \\
\hline Ibrahim (2017) & $\begin{array}{l}\text { The study was } \\
\text { carried out in } \\
\text { Makassar City, } \\
\text { Indonesia, at a } \\
\text { Local Revenue } \\
\text { Office. }\end{array}$ & $\begin{array}{l}\text { The study } \\
\text { utilised the } \\
\text { classical } \\
\text { assumption } \\
\text { test, } \quad \mathrm{N}=156 \\
\text { respondents }\end{array}$ & $\begin{array}{l}\text { The findings indicate that organisational } \\
\text { culture offers a positive effect on managerial } \\
\text { performance, which is essential for a } \\
\text { productive workforce. When an organisation } \\
\text { has good governance, the effects are felt } \\
\text { through performance and productivity. Thus, } \\
\text { an organisation needs to enhance internal } \\
\text { control in order to attain the manager's } \\
\text { performance level. } \\
\text { The probability value of having good corporate } \\
\text { governance is 0.020, which is below a } \\
\text { significant level of } 0.05 \text {. This implies that the } \\
\text { connection between having good corporate } \\
\text { governance and the managerial performance } \\
\text { variable is perceived as being statistically } \\
\text { significant. The study indicated that proper } \\
\text { execution of the internal control of the } \\
\text { company could help in making better decisions, } \\
\text { which would enhance the efficiency, as well as } \\
\text { the effectiveness of the company. }\end{array}$ & $\begin{array}{l}\text { The limitations of this } \\
\text { study include poor } \\
\text { judgment through } \\
\text { internal control tests } \\
\text { when decisions are } \\
\text { made by people under } \\
\text { pressure to offer } \\
\text { solutions based on } \\
\text { scanty information. } \\
\text { Managerial } \\
\text { performance is likely } \\
\text { to be ruined by a drop } \\
\text { in job satisfaction } \\
\text { when employees } \\
\text { become demotivated. }\end{array}$ & $\begin{array}{l}\text { Internal control, } \\
\text { organisational } \\
\text { culture, good } \\
\text { corporate } \\
\text { governance, and } \\
\text { management audit } \\
\text { had significant } \\
\text { effects on the } \\
\text { organisational } \\
\text { managerial } \\
\text { performance in the } \\
\text { organisation. } \\
\text { However, } \\
\text { organisational } \\
\text { culture does not } \\
\text { necessarily offer a } \\
\text { significant effect on } \\
\text { employee } \\
\text { productivity. }\end{array}$ \\
\hline $\begin{array}{l}\text { Harwiki, } \\
\text { (2016) }\end{array}$ & $\begin{array}{l}\text { The study covers } \\
\text { Women } \\
\text { Cooperatives in } \\
\text { East Java (on both } \\
\text { managers and } \\
\text { employees) }\end{array}$ & $\begin{array}{l}\text { The study } \\
\text { offers a } \\
\text { literature } \\
\text { review and a } \\
\text { descriptive } \\
\text { research } \\
\text { design, } \mathrm{N}=40 \\
\text { respondents. }\end{array}$ & $\begin{array}{l}\text { The findings indicate that servant leadership } \\
\text { has an impact on organisational culture, OCB, } \\
\text { organisational commitment, and employee } \\
\text { productivity. However, the findings revealed } \\
\text { that organisational culture impacts significantly } \\
\text { on OCB, but least significant on employee } \\
\text { productivity. Organisational culture's impact on } \\
\text { employee productivity is indicated by a path } \\
\text { coefficient of } 0.007 \text { and Cronbach Reliability } \\
\text { (CR) value of } 0.039 \text {. Since T-value is much } \\
\text { smaller than the CR value, the hypothesis }\left(\mathrm{H}_{0}\right) \\
\text { is accepted, which implies that organisational } \\
\text { culture does not have any significant impact on } \\
\text { employee Although } \\
\text { organisational culture is not the main } \\
\text { determinant of employee productivity, it has an } \\
\text { impact on OCB, which, in turn, impacts } \\
\text { positively on employee productivity. }\end{array}$ & $\begin{array}{l}\text { The study ignored the } \\
\text { aspect of how } \\
\text { organisational culture } \\
\text { can directly impact } \\
\text { employee productivity. } \\
\text { The study cannot be } \\
\text { replicated in other } \\
\text { organisations, as } \\
\text { descriptive studies } \\
\text { have a problem of bias } \\
\text { and loss of } \\
\text { confidentiality. } \\
\text { Additionally, studies } \\
\text { descriptive be utilised to } \\
\text { cannot be } \\
\text { determine cause and } \\
\text { effect. }\end{array}$ & $\begin{array}{l}\text { Since organisational } \\
\text { culture does not have } \\
\text { much significance on } \\
\text { employee } \\
\text { productivity, } \\
\text { managers should } \\
\text { emphasise } \\
\text { equality on } \\
\text { employees and } \\
\text { support employees in } \\
\text { embracing change in } \\
\text { their workplace. } \\
\text { Managers should } \\
\text { enhance } \\
\text { organisational } \\
\text { culture to motivate e } \\
\text { employees to } \\
\text { improve } \\
\text { performance. }\end{array}$ \\
\hline $\begin{array}{l}\text { Karneli, } \\
\text { Nimran, Al } \\
\text { Musadiq \& } \\
\text { Nayati }(2015)\end{array}$ & $\begin{array}{l}\text { The study was } \\
\text { carried out in four } \\
\text { medium scale } \\
\text { companies that } \\
\text { process food and } \\
\text { beverage in } \\
\text { Pekanbaru. }\end{array}$ & $\begin{array}{l}\text { This study is a } \\
\text { literature } \\
\text { review, with a } \\
\text { survey as a } \\
\text { method of } \\
\text { collecting } \\
\text { data. N=120 } \\
\text { people }\end{array}$ & $\begin{array}{l}\text { The most crucial findings in this study are that } \\
\text { job satisfaction offers a perfect mediation in } \\
\text { making organisational culture influence } \\
\text { employee productivity and that organisational } \\
\text { commitment mediates in making } \\
\text { entrepreneurial orientation to influence } \\
\text { employee productivity. } \\
\text { However, the findings termed organisational } \\
\text { culture as the only factor capable of enhancing } \\
\text { job satisfaction, which in turn improves the } \\
\text { employee's performance. } \\
\text { The employee's job satisfaction stood at an } \\
\text { average of } 4.03 \text {, with the highest level being } \\
4.09 \text {. This implied that employees in the SMEs } \\
\text { felt satisfied that the organisations awarded } \\
\text { them responsibilities based on their } \\
\text { capabilities. }\end{array}$ & $\begin{array}{l}\text { The study did not } \\
\text { classify the owners of } \\
\text { SMEs, while cross- } \\
\text { sectional data could be } \\
\text { biased due to the } \\
\text { failure to measure } \\
\text { incidences. }\end{array}$ & $\begin{array}{l}\text { The study indicates } \\
\text { that organisational } \\
\text { culture, as well as } \\
\text { entrepreneurial } \\
\text { orientations, do not } \\
\text { have a direct impact } \\
\text { on the employee's } \\
\text { performance. This } \\
\text { aspect implies that } \\
\text { employees have to } \\
\text { rely on } \\
\text { organisational } \\
\text { commitment and job } \\
\text { satisfaction in order } \\
\text { to enhance their } \\
\text { performance. }\end{array}$ \\
\hline $\begin{array}{l}\text { Pawirosumarto, } \\
\text { Setyadi\& } \\
\text { Khumaedi } \\
(2017) .\end{array}$ & $\begin{array}{l}\text { This study covers } \\
\text { non-lecturer } \\
\text { employees } \\
\text { working at the } \\
\text { University of } \\
\text { Mercu Buana. }\end{array}$ & $\begin{array}{l}\text { The study is a } \\
\text { survey done } \\
\text { through } \\
\text { confirmatory } \\
\text { research and } \\
\text { descriptive } \\
\text { statistical } \\
\text { analysis; } \\
\mathrm{N}=60 \\
\text { respondents } \\
\text { were chosen } \\
\text { through } \\
\text { proportional } \\
\text { random } \\
\text { sampling. }\end{array}$ & $\begin{array}{l}\text { The findings illustrated that consistency, as } \\
\text { well as adaptability, do not influence the work } \\
\text { performance of employees within higher } \\
\text { education institutions. Some indicators of job } \\
\text { performance include quality, punctuality, } \\
\text { effectiveness, and independence. The validity } \\
\text { and reliability tests indicate a high score on all } \\
\text { independent variables (Involvement }-0.838 \text {, } \\
\text { adaptability - } 0.738 \text {, consistency - } 0.742 \text {, } \\
\text { mission - } 0.855 \text { ). The above scores confirm } \\
\text { that the study is reliable, as all scores are above } \\
0.70 \text {. Additionally, the study perceives the } \\
\text { organisational culture of mission as having the } \\
t \text {-statistic of } 2.973 \text {, as well as the significance } \\
\text { of } 0,003 \text {, which is below the standard measure } \\
\text { of } 0.05 \text {. }\end{array}$ & $\begin{array}{l}\text { The study does not } \\
\text { indicate the limitations } \\
\text { of having the four } \\
\text { types of organisational } \\
\text { culture to influence the } \\
\text { performance of the } \\
\text { non-lecturer } \\
\text { employees. While } \\
\text { confirmatory research } \\
\text { is done to test a priori } \\
\text { hypotheses, its } \\
\text { limitation is that } \\
\text { analyses are driven by } \\
\text { preconceived ideas and } \\
\text { that it is quite hard to } \\
\text { notice unanticipated } \\
\text { results. }\end{array}$ & $\begin{array}{l}\text { Organisational } \\
\text { culture, particularly } \\
\text { the culture of } \\
\text { involvement, plays a } \\
\text { vital role } \\
\text { enhancing the } \\
\text { performance of non- } \\
\text { lecturer workers. } \\
\text { However, } \\
\text { organisational the } \\
\text { culture of } \\
\text { consistency and } \\
\text { adaptability hardly } \\
\text { affect } \\
\text { performance of non- } \\
\text { lecturer employees. }\end{array}$ \\
\hline
\end{tabular}

\section{Discussion}

Employees are committed to their job when they feel that they have job stability, are able to balance work with family life, and have an opportunity for career growth. According to Meng and Berger (2019), organisational culture and leadership performance are crucial factors for work engagement, commitment, as well as job satisfaction. Employees cannot perform effectively when they are not satisfied with what the organisations are 
offering them. Karneli et al. (2015) asserted that organisational culture is the key factor for enhancing job satisfaction after the outer testing model revealed that 13 indicators of job satisfaction could be significant indicators. When employees are not satisfied with their job, they tend to lower their productivity, experience job stress and may opt to leave their current workplace for better jobs elsewhere.

Organisational commitment facilitates job satisfaction to improve employee productivity. Accordingly, organisations can enhance job satisfaction by improving communication, time management, healthy competition, proper explanation of tasks, and enhancing team skills (Sivakami \& Samitha, 2018). Supportive organisational conditions can be the key drivers to increased job satisfaction among employees; thus, organisations should focus on supportive organisational culture to ensure that their employees are satisfied with their responsibilities (Meng \& Berger, 2019). A supportive organisational culture improves employee engagement makes them feel respected and valued by the organisation. When employees experience job satisfaction, they demonstrate a commitment to the organisation (Karneli et al., 2015). Thus, job satisfaction has a positive impact on organisational commitment.

Corporate culture involves interactions of humans in an organisation, where they share values, beliefs, attitudes, and standards that correspond to organisational goals. Naranjo-Valencia, Jimenez-Jimenez and SanzValle (2016) link organisational culture to employee commitment through the stimulation of innovative behaviours, as well as maintaining consistency in attaining organisational objectives. Shah and Parmar (2016) termed organisational culture as expectations, values, philosophy, and experiences that hold an organisation together. Organisational culture affects productivity, as well as the performance of an organisation by offering guidelines on how to attend to customers and how to enhance safety and product quality. A study by Taylor et al. (2016) indicated that most organisations that have cultural support demonstrated greater improvement in terms of productivity than organisations with no cultural support. An appropriate organisational culture goes together with supportive leadership, as organisations with no supportive leadership may experience poor performance. The study by Braithwaite et al. (2017) offers a systematic review of organisational culture that has contributed to enhancing patient outcomes. The study reveals a consistency in the association between organisational culture and employee outcomes across various studies, settings, as well as countries.

Although Hendrik, Moch, Madhakomala and Suratman (2018) have indicated several variables that may influence employee productivity, they have highlighted organisational culture as among the key aspects that directly impact employee productivity. Harwiki (2016) also indicated that organisational culture, organisational citizenship behaviours (OCB), organisational commitment, and servant leadership have an impact on employees' productivity. Isa, Ugheoke and Noor (2016) emphasised that the integration between employees and their organisations is vital for enhancing their productivity and commitment. When employees are not satisfied by the organisational culture, they tend to perform poorly and may opt to leave their current organisations or demonstrate a lack of commitment, which would interfere with their productivity. According to Karneli et al. (2015), organisational culture contributes towards job satisfaction, which, in turn, improves employee's productivity. Pawirosumarto, Setyadi and Khumaedi (2017) tested employee commitment by focusing on consistency, mission, and adaptability simultaneously can have a significant influence on the productivity of employees.

In a child welfare organisation, youth outcomes are enhanced by developing proficient organisational cultures, which in turn minimise staff turnover and improve the productivity of caseworkers who respond to the youth's needs, as well as the families involved in the welfare (Williams \& Glisson, 2013). Software firms can enhance their competitive market position by focusing on software process improvement (SPI), which emphasises knowledge management practices and organisational culture (Lee, Shiue \& Chen, 2016). This is because organisational culture transforms the way employees think, in addition to responding to processes involved in developing products. Ibrahim (2017) took a different perspective by focusing on how organisational culture has influenced managerial performance, which implied that culture determines how managers should conduct themselves when dealing with employees.

On the other hand, employees seek organisations that offer a good physical environment, which motivate them to improve productivity (Paschal \& Nizam, 2016). Employee productivity is termed as an outcome attained by employees through their capacity to work and motivation (Sahat et al., 2018). According to Ibrahim (2017), managerial performance is critical in the organisation, as it assists in bringing success to the organisation through encouraging and motivating employees to perform to their best. The findings by Ibrahim (2017) indicated that the probability value of having good governance is 0,020 , which is lower than the required significance level of 0.05 , which implies that the effect that good governance has on managerial performance is statistically significant. Entrepreneurial orientation and organisational commitment play a significant role in ensuring that employees have improved in their productivity through motivation (Karneli Nimran, Al Musadiq \& Nayati, 2015).

The turnover-productivity relationship in service organisations is likely to improve when employees are satisfied through organisational culture. According to Williams and Glisson (2013), the link between employee 
turnover and the productivity of the organisation is explained appropriately through human and social capital theories. However, Harwiki (2017) has indicated that the impact of organisational culture is not significant on employees' productivity. Unlike Harwiki (2017), Sahat et al. (2018) outlined six criteria to measure individual employees' productivity. They include quality, quantity, effectiveness, timeliness, autonomy, and work commitment, which are critical components of organisational culture.

The comparison of studies by Sivakami and Samitha (2018) and Williams and Glisson (2013) revealed how organisations could make use of organisational culture to enhance their operations and improve their outcome through motivation. However, Sivakami and Samitha (2018) utilised the non-probability sampling method to collect data that could offer an answer to the problem statement. The limitation of non-probability sampling is that Williams and Glisson (2013) used a probability survey method to study the youth who have been abused and neglected and to evaluate the hypotheses. Williams and Glisson (2013) also applied stratified sampling, where the population under study is categorised into separate groups to enhance equal representation in the sample. However, only one study by Harwiki (2016) indicated that organisational study does not have any significance in determining employee productivity. The path coefficient in this study is 0.007 , while the Cronbach Reliability (CR) value is 0.039 . When the $\mathrm{T}$-value is less than the $\mathrm{CR}$ value, it implies that organisational culture lacks a significant impact on employee productivity; thus, it may not be used to motivate employees.

Isa, Ugheoke and Noor (2016) are interested in understanding the connection between employee productivity and organisational culture in the public sector since public sector organisations are mostly interested in non-financial measures of employee productivity. The findings by Pawirosumarto, Setyadi and Khumaedi (2017) revealed a significant influence of the culture of involvement on improving the productivity of employees, with a $t$ statistic of 5.009 and a significance of 0.000 , which is less than 0.05 . Naranjo-Valencia, JimenezJimenez and Sanz-Valle (2016) highlighted the connection between innovation and productivity by indicating that culture can stimulate or restrain innovation and, hence, affect the productivity of the organisation. However, the authors believed that an adhocracy culture offers the best platform for innovation to influence productivity.

Employees are willing to work in certain organisations because they are motivated toward achieving goals not only for the organisations that they work for but also for their own personal goals (Karneli et al., 2015). Sahat et al. (2018) indicated that employee productivity is guided by the interactions between his/her ability and the level of motivation. Thus, productivity has to be influenced by something that creates meaning for the organisation. If the organisation's management demonstrates that it values its workforce, it will motivate employees to improve their productivity and, consequently, it would manage to meet its goals effectively (Sivakami \& Samitha, 2018). Lack of opportunities for employees with desires to prosper in business may make them lose the desire and motivation to remain committed to their organisation (Karnelli et al., 2015).

Organisations can motivate their employees by involving them in decision-making processes, in addition to allowing them to have a sense of autonomy while undertaking their duties (Pawirosumarto, Setyadi \& Khumaedi, 2017). Employees will always feel motivated when they are allowed to make decisions on their own and to compete fairly, which would ultimately make them remain loyal to the organisation by improving their productivity. Additionally, organisations that have adopted hierarchical culture are able to motivate their employees to share knowledge, experience, as well as skills that are related to their responsibilities (Lee, Shiue \& Chen, 2016). Thus, organisations can contribute towards the improvement of employee productivity by establishing appropriate organisational culture.

The culture of the organisation has to be highlighted in order to bring out all the vital features of the organisation (Paschal \& Nizal, 2016). By carrying out a specified study using distributed questionnaires, Salehipour and Ahmand (2018) have demonstrated how organisational culture is strongly linked to employees' productivity even in a public organisation. Pawirosumarto, Setyadi and Khumaedi (2017), Harwiki (2016), Paschal and Nizam (2016), and Naranjo-Valencia, Jimenez-Jimenez and Sanz-Valle (2016) used descriptive statistical analysis to prove that organisational culture has a positive and significant influence on how employees perform in their workplace. The findings recommend that organisations should take actions that would motivate employees in their workplace to give desired outcomes.

Culture involves shared attitudes, customs, beliefs, as well as written and unwritten rules, which develop within the workplace over time. Culture can make employees demonstrate either a positive or negative attitude towards their jobs. Naranjo-Valencia, Jimenez-Jimenez and Sanz-Valle (2016) came up with a new idea that innovation is more influential than organisational culture when it comes to maintaining the long-term success of the organisation, in addition to maintaining a positive attitude among employees. Leaders who utilise adhocracy culture are able to exploit innovative ideas to enhance good performance among employees. The aspect of innovation is supported by Hendrik et al. (2018), who emphasised that managers must strive to implement innovation because it is part of transformational leadership and which facilitates attaining desirable results from employees. Managers should motivate employees to come up with innovative ideas that can enhance their productivity.

While Lee, Shiue and Chen (2016) offered room for further studies concerning the topic, in conclusion, 
Karneli et al. (2015) and Taylor et al. (2018) did not find it necessary to have further studies on how organisational culture could be reviewed to have more influence on employee productivity. Paschal and Nizam (2016) and Salehipour and Ah mand (2018) concluded by encouraging organisations to review their organisational cultures in order to meet the needs of their stakeholders, as well as improve the productivity of their employees. Naranjo-Valencia, Jimenez-Jimenez and Sanz-Valle (2016) were convinced that future research was necessary to elaborate on the link between culture and innovation since organisational traits involved in the implementation of innovation may vary. Braithwaite et al. (2017) recommended better-quality studies to confirm or reject evidence offered in their synthesis.

A comparison between the studies by Isa, Ugheoke and Noor (2016) and Karneli et al. (2015) reveals a similarity in terms of the influence of organisational culture on employees' attitudes and whether the relationship between the culture and productivity is significant. Paschal and Nizam (2016) utilised questionnaires to gather data on how symbols, heroes, rituals, and values motivate employees to improve their productivity. Isa, Ugheoke and Noor (2016) also utilised questionnaires to carry out the survey, where bureaucratic culture depicted a beta value of 0.341 , which is relatively high in terms of significance.

Different authors utilised different research designs to offer significant and correct conclusions based on how culture motivates employees to boost their productivity. Culture can influence a positive attitude among employees, especially where leaders demonstrate trust to employees. The designs used in the studies are exhaustive because they managed to bring out an appropriate explanation of the research topic, as well as answer the hypotheses on the influence of corporate culture. The study by Salehipour and Ahmand (2018) utilised a simple random sampling method to elaborate on how the High-Performance Work System (HPWS), as well as the organisational culture, influence employees' productivity in the Ministry of Education in Iran. The article concluded that organisations should recognise the need to meet stakeholders' expectations by promoting a better culture that motivates employees to improve their productivity. Sivakami and Samitha (2018) utilised a nonprobability sampling design to carry out a survey on employees of a software technologies company since the design offers convenience and capacity to meet the purpose of the study. Sahat et al. (2018) utilised a quantitative research approach to collect data and generalised structured component analysis (GSCA) to perform analysis.

Organisational culture is involved in strengthening the connection between supportive leadership traits and organisational commitment, which assists employees in meeting the organisation's set goals (Isa, Ugheoke \& Noor, 2016). From the study by Hendrik et al. (2018), transformational leadership is essential for improving the productivity of employees by encouraging them to develop positive attitudes and appropriate behaviours that are tied to the corporate culture. Sahat et al. (2018) indicate that although servant leadership does not have much influence on the performance of employees, it encourages the use of rewards to encourage employees to improve their productivity. Besides, organisations with supportive leadership tend to be more likely to experience substantial improvement in employee productivity and health risks than organisations that lack supportive leadership (Taylor et al., 2018). Shah and Parmar (2016) recognised that leadership is paramount in ensuring that employees are capable of working optimally. Effective leadership is a critical factor for transforming the culture of the organisation (Shah \& Parmar, 2016). While most authors focused on how organisational culture affects employees' productivity, Meng and Berger (2019) utilised a cross-sectional and online survey to evaluate how organisational culture, as well as leading performance, could influence public relation professionals' work participation and job satisfaction. Sahat et al. (2018) are concerned about other factors that affect the productivity of employees instead of exclusively focusing on the organisational culture. After going through several articles, Braithwaite et al. (2017) used a systematic review to discover that positive organisational culture, as well as appropriate workplace behaviours, can facilitate in improving patient outcomes, leading to reduced mortality, shorter hospital stay, and decreased pain level.

The literature review in the studies by Hendrik et al. (2018) and Isa, Ugheoke and Noor (2016) offers an overview of leaders can utilise change management to enhance organisational culture, which in turn improve the productivity of employees. The reviews in these studies are comprehensive and have cited references that are relevant to the issue of the influence of organisational culture on the productivity of employees. Sahat et al. (2018) cited Robbins (2003) in the definition of organisational culture, where he explained that organisational members establish a system of shared values and meaning, which differentiate an organisation from another. However, some of the articles oppose the view that organisational culture has a significant influence on the productivity of employees. Harwiki (2016) indicated organisational culture does not have a significant effect on employee productivity; hence, a change in the value of organisational culture will not create any change in the value of employee productivity.

The findings of statistical research carried out by Sivakami and Samitha (2018) confirmed the strength and significance of the relationship between organisational culture and employee productivity through leadership. The study utilised 12 questions, which were distributed to the organisation's employees. While $48 \%$ of the respondents felt that having the necessary skills was essential for organisational success, $23 \%$ of the respondents 
mentioned better communication as vital for meeting expected standards. While the study by Shah and Parmar (2016) indicated that organisational culture is enough to influence employee productivity, another study by Muliaty, Basri and Jasruddin (2017) claimed that organisational culture should be accompanied by transformational leadership to have an effect on employee productivity and to achieve job satisfaction.

The study by Muliaty, Basri and Jasruddin (2017) can be compared to the study by Paschal, Setyadi and Khumaendi (2017) to demonstrate their similarities in terms of organisational culture and effective leadership. The two studies also utilise surveys as a method of gathering data for the research, where the former employs exploratory research design while the latter uses a descriptive research design to explain the research process. Both studies indicated in their findings that organisational culture plays a vital role in enhancing the performance of employees through leadership. The statistical report by Muliaty, Basri and Jasruddin (2017) demonstrated two significant paths within the path analysis, which include job satisfaction to employee productivity and organisational transformation to job satisfaction, with standardised coefficients of 0,690 and 0,700 , respectively. Both studies concluded that organisational culture is fundamental for organisational leaders to improve employee productivity.

The findings from the articles offer a lesson on how leaders in organisations can improve their productivity without necessarily increasing their expenses. According to Sivakami and Samitha (2018), managers should take measures by conducting training employees on management skills, as well as inculcating behaviours that match with their responsibilities in order to improve their productivity. Employee turnover can be solved by creating an environment that supports employee outcomes, in addition to linking performance with organisational culture (Williams \& Glisson, 2013). Paschal and Nizam, 2016) revealed that organisational culture could be conveyed in numerous ways, which include symbols, rituals, and heroes. This implies that contemporary organisations should strive to meet their stakeholders' expectations by adopting behaviours and acts that promote teamwork and commitment.

Salehipour and Ah mand (2018) carried out hypothesis testing using linear regressions, where the Pearson correlation analysis helped in the understanding of the linkage between organisational culture, HPW, and employee's performance. Additionally, a study by Meng and Berger (2019) incorporated specific hypotheses, which are tested to demonstrate that effective leadership is vital for enhancing employee productivity. The study utilised an online survey to test all the hypotheses, as well as a random sampling strategy to enhance the generalizability of the results. Pawirosumarto, Setyadi and Khumaedi (2017) used descriptive statistical analysis to demonstrate the effects of the relationship between variables. The sample used in the study by Muliaty, Basri and Jasruddin (2017) was relatively small to come up with an appropriate sample.

\section{Conclusion}

The research question in this study is: For organisational employees working in medium-size and large-size enterprises, how does a strong organisational culture compared to weak organisational culture affect workforce productivity. Meng and Berger (2019) termed organisational culture as a compilation of beliefs, values, as well as assumptions, which are shared by members working in the same organisation. The shared values influence the behaviours of organisational members, as values are essential for guiding their decisions, leading to organisational effectiveness. The views by Meng and Berger (2019) are also supported by Sahat et al. (2018), who indicated that organisational culture has a significant effect on the performance of employees.

Organisations can successfully accomplish their goals if they are managed by effective leaders who motivate employees and who are not afraid to make changes that have an impact on employees. Hendrik, Moch, Madhakomala and Suratman (2018) encourage leaders to adopt a transformational leadership style, which can assist in enhancing employees' performance. Some of the changes made during the implementation of the most appropriate organisational culture should be addressed within the dynamic context. Creating a good physical environment can help in developing a mindset that motivates employees to improve their performance and meet organisational goals (Paschal \& Nizam, 2016).

The significance of organisational culture to transform employees should be backed with proof that the right process was used to collect and analyse the data. The study by Karneli et al. (2015) aimed at proving that organisational culture is the key factor in enhancing job satisfaction and, in turn, improving the employees' performance. The study indicates that organisational culture, as well as entrepreneurial orientation, may not influence the employee's performance directly unless job satisfaction is included as the mediating factor.

By undertaking a specified study based on distributed survey questionnaires, the study by Salehipour and Ah mand (2018) focused on enhancing employees' performance in order to create a high-performance work system (HPWS), as well as an organisational culture based on employee productivity. After undertaking a qualitative design in the collection of data from 120 respondents in 4 companies in Pekanbaru, Karneli et al. (2015) found that job satisfaction influences organisation culture, which in turn influences employees' performance.

Organisation culture is vital for preventing employees' turnover and enhancing commitment to their duties. 
The relationship that exists between employees' turnover and their performance is usually explained through human and social capital theories (Williams \& Glisson, 2013). The social capital theory emphasises the need to have interpersonal relationships, as well as tie the quality to an organisation's effectiveness. The theory indicates that developing networks of interpersonal relationships over time helps in enhancing organisational performance through the application of knowledge.

The organisational culture encourages employees to be more innovative and creative, which in turn make them perform optimally for the benefit of the organisation. Naranjo-Valencia, Jimenez-Jimenez and Sanz-Valle (2016) emphasised adhocracy culture to foster innovation, in addition to improving the company's performance. The findings by Shah and Parmar (2016) reveal that employees are able to create an understanding that helps them to work as a team by developing working ethics and culture. Pawirosumarto, Setyadi and Khumaedi (2017) indicated that consistency and adaptability have no influence on the work performance of employees in the framework of higher education institutions but are significant in motivating employees to boost their performance.

Organisational culture can be strengthened by ensuring that employees are satisfied with their jobs. The study by Isa, Ugheoke and Noor (2016) concluded by supporting the bureaucratic culture as the culture that has a significant effect on the performance of the employees, owing to the strength of bureaucracy in organisations based in the Gulf. However, the study claimed that the limited sample utilised in the study did not offer an appropriate representation of the population in the Gulf countries. The strength of organisational culture is also supported by Menga and Berger (2019), who emphasised the mediating effects of trust and engagement in enhancing professionals' job satisfaction.

The findings by Sahat et al. (2018) revealed that servant leadership influences organisational culture but does not influence employee productivity. Organisational culture is considered as the key factor in offering a significant influence on employee productivity, while rewards have a strong influence on organisational culture. However, Karnelli et al. (2015) asserted that organisational culture and entrepreneurial position do not have a direct influence on the employee's performance unless the aspect of job satisfaction, as well as organisational commitment, are incorporated in the culture to enhance their performance. Hendrik et al. (2018) hold the view that there is an indirect but positive influence of organisational culture on employee productivity in transformational leadership.

The limitations offered in various research studies inform organisational leaders to be keen when choosing the most appropriate concepts to incorporate in organisational culture. Isa, Ugheoke and Noor (2016) warn organisations against using the research findings from the Gulf region, as they do not portray consistency or offer the verification of the cause and effect. Braithwaite et al. (2017) insist on consistency in the studies on culture to offer positive implications on patient outcomes. More rigorous intervention studies are necessary to promote changes in organisational culture, which could ultimately enhance patient outcomes.

The study on how the performance of employees is influenced by organisational culture offers an insight into how managers should treat employees in order to improve the productivity of their organisations. They should contribute toward employee productivity by motivating them and ensuring that they are satisfied with their job. Additionally, they should identify factors that make employees fail to achieve the organisational goals so that they can review them on time to avoid dismal performance. On the other hand, employees should possess skills and motivation to work since they contribute to making the organisation improve productivity. As long as employees have clearly defined goals, they are capable of attaining the goals through following appropriate organisational culture.

\section{References}

Afsar, B., \& Umrani, W. A. (2019). Transformational leadership and innovative work behaviour. European Journal of Innovation Management.

Alvesson, M. (2012). Understanding organisational culture. Sage.

Becker, T. E., Kernan, M. C., Clark, K. D., \& Klein, H. J. (2018). Dual commitments to organisations and professions: Different motivational pathways to productivity. Journal of Management, 44(3), 1202-1225.

Booth, A., Sutton, A., \& Papaioannou, D. (2016). Systematic approaches to a successful literature review. Sage.

Braithwaite, J., Herkes, J., Ludlow, K., Testa, L., \& Lamprell, G. (2017). Association between organisational and workplace cultures, and patient outcomes: a systematic review. BMJ Open, 7(11), e017708.

Hartnell, C. A., Ou, A. Y., \& Kinicki, A. (2011). Organisational culture and organisational effectiveness: A meta-analytic investigation of the competing values framework's theoretical suppositions. Journal of applied psychology, 96(4), 677.

Harwiki, W. (2016). The impact of servant leadership on organisation culture, organisational commitment, organisational citizenship behaviour (OCB) and employee productivity in women cooperatives. ProcediaSocial and Behavioral Sciences, 219, 283-290.

Hendrik, G. S., Moch A., Madhakomala, R., \& Suratman, A. (2018). Effect of change in management, 
organisational culture and transformational leadership on employee productivity PT. AdhyaTirta Batam (PT. ATB). International Review of Management and Marketing, 8(6), 15-23.

Ibrahim, M. (2017). Effects of internal control, corporate governance, organisational culture, and management audit on managerial performance: Evidence from Indonesia. Journal of Economic \& Management Perspectives, 11(3), 1826-1832.

Isa, M. F. M., Ugheoke, S. O., \& Noor, W. S. W. M. (2016). The influence of organisational culture on employees' performance: evidence from Oman. Journal of Entrepreneurship and Business, 4(2), 1-12.

Karneli, O., Nimran, U., Al Musadiq, \& Nayati, U. H. (2015). The influence of organisational culture and entrepreneurial orientation on job satisfaction, organisational commitment, and employee's performance. European Journal of Business and Management, 7(2), 55-68.

Lăzăroiu, G. (2015). Work motivation and organisational behaviour. Contemporary Readings in Law and Social Justice, 7(2), 66-75.

Lee, J. C., Shiue, Y. C. \& Chen, C. Y. (2016). Examining the impacts of organisational culture and top management support of knowledge sharing on the success of software process improvement. Computers in Human Behavior, 54, 462-474.

Meng, J., \& Berger, B. K. (2019). The impact of organisational culture and leadership performance on PR professionals' job satisfaction: Testing the joint mediating effects of engagement and trust. Public Relations Review, 45(1), 64-75.

Muliaty, M., Basri, M., \& Jasruddin, J. (2017). Effects of Organizational Transformation and Culture on Employees Performance. Journal of Economic \& Management Perspectives, 11(3), 1287-1292.

Nahemow, L., Lawton, M. P., \& Center, P. G. (2016). Toward an ecological theory of adaptation and ageing 13. Environmental Design Research: Volume one selected papers.

Naranjo-Valencia, J. C., Jimenez-Jimenez, D., \& Sanz-Valle, R. (2016). Studying the links between organizational culture, innovation, and performance in Spanish companies. Revista Latinoamericana de Psicología, 48(1), 30-41.

Naranjo-Valencia, J. C., Jiménez-Jiménez, D., \& Sanz-Valle, R. (2011). Innovation or imitation? The role of organizational culture. Management Decision, 49(1), 55-72.

Ostroff, C., Kinicki, A. J., \& Muhammad, R. S. (2012). Organisational culture and climate. Handbook of Psychology, Second Edition, 12. research, 63(7), 763-771.

Parsons, T. (2017). The present status of "structural-functional" theory in sociology. The idea of social structure(pp. 67-84). Routledge.

Paschal, A. O., \& Nizam, I. (2016). Effects of organisational culture on an employees performance: Case of Singapore telecommunication. International Journal of Accounting \& Business Management, 4(1), 19-26.

Pawirosumarto, S., Setyadi, A., \& Khumaedi, E. (2017). The influence of organisational culture on the performance of employees at the University of Mercu Buana. International Journal of Law and Management, 59(6), 950-963.

Ramdhani, A., Ramdhani, M. A., \& Ainissyifa, H. (2017). Conceptual Framework of Corporate Culture Influenced on Employees Commitment to Organization. International Business Management, 11(3), 826830.

Sahat, S., Astuti, E. S., Mochammad, A. M., Djamhur, H., \& Kusdi, R. (2018). The effect of servant leadership on rewards, organisational culture and its implication for employee's performance. International Journal of Law and Management, 60(2), 505-516.

Salehipour, A., \& Ah, mand, A. (2018). The Impact of Organizational Culture and Performance Work System on Employees' Performance. International Business Research, 11(6), 199-212.

Schein, E. H. (2011). Organisational culture and leadership(Vol. 2). John Wiley \& Sons.

Shah, K., \& Parmar, C. (2016). A Study on diverse parameters of Organizational Culture \& its impact on employees Performance. Globsyn Management Journal, 10(1/2), 39-49.

Sivakami, R., \& Samitha, S. S. (2018). A study on the impact of organisational culture on employee productivity. International Journal of Management Research and Reviews, 8(7), 1-8.

Taylor, W. C., Suminski, R. R., Das, B. M., Paxton, R. J., \& Craig, D. W. (2018). Organisational culture and implications for workplace interventions to reduce sitting time among office-based workers: A Systematic Review. Frontiers in Public Health, 6, 1-14.

Williams, N. J., \& Glisson, C. (2013). Reducing turnover is not enough: The need for proficient organisational cultures to support positive youth outcomes in child welfare. Children and youth services review, 35(11), 1871-1877.

Zheng, W., Yang, B., \& McLean, G. N. (2011). Linking organisational culture, structure, strategy, and organisational effectiveness: Mediating role of knowledge management. Journal of Business 